\title{
David Nirenberg \\ Neighboring Faiths: Christianity, Islam, and Judaism in the Middle Ages and Today
}

(Chicago and London: University of Chicago Press, 2014), hardcover, v + 341 pp.

\author{
HANNAH JOHNSON \\ hrj4@pitt.edu \\ University of Pittsburgh, Pittsburgh, PA 15260
}

Neighboring Faiths is in the main an edited and reworked collection of previously published articles (only the Introduction and Chapter 4 are original to this volume), and the book shows some traces of this, despite those editorial interventions. Chapter 1, titled "Christendom and Islam," for example, was originally composed for an introductory collection, The Cambridge History of Christianity, and the careful exposition here still reads like what it is: a smart, sure-footed general overview offered by an expert teacher. Because of this history behind the book's composition, readers hoping for a work systematically constructed around the major terms listed in the title-Christianity, Islam, and Judaism-may be somewhat disappointed by the comparatively less attention given to Islam in these pages. However, the conceptual richness of the material more than justifies the decision to gather this work together in one volume. The arguments in the different chapters enter into productive dialogue with one another, resounding with shared concerns even when they do not precisely line up as different pieces of a single thesis, as chapters in a monograph typically do. In this context, the title should perhaps be imagined as a heuristic device, referencing the major terms that appear in these pages, certainly, but also signaling the book's ambition to open up a more nuanced and wide-ranging analysis of what Nirenberg calls the "coproduction" (p. 5, et passim) of religious identity between these different faith traditions, particularly in medieval Iberia. With this term, Nirenberg signals the importance of group identity formation in constant relation to neighboring communities, in which Christians, Muslims, and Jews define their own identities through acts of measuring, distancing, and sometimes appropriating aspects of other communities' formations. While Nirenberg is not the first to explore this model of identity formation in relation to religious communities, he nevertheless offers a number of new insights regarding its historical functioning "on the ground," particularly in his analysis of significant cultural shifts leading to some well-known developments, such as the emergence of the late medieval purity of blood statutes. 
The early chapters explore some of the complexities of inter-faith relations in medieval Iberia. After his overview of Christian-Muslim relations, Nirenberg explores anxieties and prohibitions concerning sexual relationships across religious lines. In "Love Between Muslim and Jew" (chapter 2), Nirenberg considers these complex views of sexuality as they relate to inter-group politics and social relations. He illustrates how each community's response to issues of sexual dalliance, conversion, and marriage was conditioned by its place in a complex religious hierarchy. This hierarchy itself was unstable, notably shifting, Nirenberg argues, after the tumultuous events of the late fourteenth century described in later pages. In chapter 3, "Deviant Politics and Jewish Love: Alfonso VIII and the Jewess of Toledo," Nirenberg excavates the political resonances of accusations of "Jew love" (p. 63) in medieval Castile, where stories about a king's Jewish concubine could function as intricate political parables about proper governance, administration, and authority.

The structural center of Neighboring Communities is arguably chapter 4, "Massacre or Miracle? Valencia, 1391," composed specifically for this volume, which functions as a lynchpin for arguments that come before and after it. Nirenberg highlights the pivotal importance of that year, when massacres and mass conversions of Jews in several Iberian polities profoundly reshaped the religious landscape. Using the example of Valencia, Nirenberg illuminates how King Joan's efforts to quell the violence and punish those who instigated it encountered significant challenges, as Valencia's city fathers framed the events as evidence of a "miraculous" intervention that trumped the king's authority. Like so many chapters in this volume, the argument here is nuanced in ways that resist brief summary. However, this piece emphasizes an essential theme explored in most of the remaining pages, as Nirenberg writes that the aftermath of 1391 eventually "produce[d] a revolution in the social and theological understanding of what it meant to be Christian" (p. 76).

This is where Nirenberg's argument about the "coproduction" of identities shifts into high gear. In the following four chapters he examines specific moments in this process by which mass Jewish conversions introduced both disorientation among Christians about the boundaries of religious identity and a growing desire to reestablish those boundaries. These chapters cover considerable ground: post-1391 renegotiations of sexual and social boundaries called into question by conversions (chapter 5); the discourse of Judaism and Jewishness as an evolving poetic trope in the medieval Canconiero, linked in complex ways to issues of both identity and some familiar dualities from Christian theology (chapter 6); the emergence of a "genealogical turn" (p. 167) in the century after the mass conversions among Old Christians, New Christians, and Jews that recalibrated the relations between genealogy, status, and identity (chapter 7); and a reflection on the place of late medieval Iberian history, with its preoccupations about blood and identity, in debates about the history of race (chapter 8). Each of these chapters merits its own lengthy consideration. Each is a thoughtful and even-handed re-examination of some received scholarly wisdoms as well as an argument on its own terms. Collectively, these chapters paint a multi-faceted por- 
trait of evolving inter-group relations in late medieval Iberia. There is nothing pre-ordained about this evolution, in Nirenberg's view, nor are these processes inexplicable. Instead, through careful analysis and synthesis of an impressively wide field of evidence, Nirenberg is able to engage with the specific contours of medieval Iberian thinking across religious lines as concepts of identity evolve. He emphasizes how newly unsettled ideas about religious classification following the conversions of 1391 gradually yielded increasingly insistent efforts to assert and control those categories once more, using the tools of genealogy and legislation to these ends.

Readers of Nirenberg's previous works may see a certain continuity of emphasis in these pages on historical, local specificity and a refusal of a teleological view of inter-religious relations, in which early beginnings predict much later historical developments. There is a modest return to a certain "myth-busting" ethos in the final chapter (chapter 9), where Nirenberg anatomizes two modern Western modes of engagement with Islam - exclusion and inclusion-that paradoxically reinforce broadly similar patterns of thought. Here the book's references to some continuing modern dilemmas of identity and relation, signaled many times, are most thoroughly developed. Neighboring Communities is the work of a mature and sophisticated scholar with much to teach us about some questions of religious identity and inter-group relations that continue to be relevant to our own tumultuous times. 